\title{
Analysis of Children's Motor Ability with Special Needs in Terms of the Teacher's Role and Comparison of Physical Fitness
}

\author{
$1^{\text {st }}$ Gatot Jariono \\ Sports Education, Teacher \\ Training and Education Faculty \\ Universitas Muhammadiyah \\ Surakarta \\ Surakarta, Jawa Tengah, \\ Indonesia \\ 9j969@ums.ac.id \\ $4^{\text {th }}$ Ardhian Tomy Kurniawan \\ Sports Education, Teacher \\ Training and Education Faculty \\ Universitas Muhammadiyah \\ Surakarta \\ Surakarta, Jawa Tengah, \\ Indonesia \\ atk317@ums.ac.id
}

\author{
$2^{\text {nd }}$ Nurhidayat \\ Sports Education, Teacher \\ Training and Education Faculty \\ Universitas Muhammadiyah \\ Surakarta \\ Surakarta, Jawa Tengah, \\ Indonesia \\ nur574@ums.ac.id \\ $5^{\text {th }}$ Chandra Triadi \\ Sports Education, Teacher \\ Training and Education Faculty \\ Universitas Muhammadiyah \\ Surakarta \\ Surakarta, Jawa Tengah, \\ Indonesia \\ a810170080@student.ums.ac.id
}

\author{
$3^{\text {rd }}$ Eko Sudarmanto \\ Sports Education, Teacher \\ Training and Education Faculty \\ Universitas Muhammadiyah \\ Surakarta \\ Surakarta, Jawa Tengah, \\ Indonesia \\ es348@ums.ac.id \\ $6^{\text {th }}$ Maimunah Nur Anisa \\ Sports Education, Teacher \\ Training and Education Faculty \\ Universitas Muhammadiyah \\ Surakarta \\ Surakarta, Jawa Tengah, \\ Indonesia \\ a810170010@student.ums.ac.id
}

\begin{abstract}
The purpose of this study is to analyze and describe the motoric abilities of children with special needs reviewed from physical fitness. The population and sample of this study are students of SLBN Sukoharjo and SLBN Karanganyar as many as 30 people with characteristics of 13-15 years old with the gender of the son consisting of 15 people SLBN Karanganyar and 15 people SLBN Sukoharjo and teachers as many as 30 people. The analysis used in this study is $t$ test at a significant level of 0.05 overall data analysis using the help of Statistical Package for the Social Sciences (SPSS) version 23 . The results of this study showed that the motoric ability of children with special needs reviewed from physical fitness has a significant difference. However, further research is needed by involving other variables related to distinguishing the physical fitness of children with special needs, one of which is social environmental factors, family support, peers, physical activity, and those related to this study. Thus, it can be concluded that this study has differences in motoric ability to review the physical fitness of children with special needs while the role of teachers consists of teachers as educators, mentors, designers of learning, artists/actors, mediators, and motivators.
\end{abstract}

Keywords-motoric ability, teacher role, physical fitness, children with special needs

\section{INTRODUCTION}

The characteristics of children with special needs consist of the blind, deaf, speech deaf, autistic, hyperactive or attention deficit hyperactivity disorder (ADHD), and multiple deafnesses[1]-[4]. Note that if children with special needs are not given activities in the form of physical activity, one of them is through motor skills exercises that are reviewed from the physical fitness of children with special needs. One of the right containers to overcome the impact that will occur to the series of problems in the future is through education, one of the studies to foster a healthy lifestyle is through physical education of sports, and health in schools. The implementation of physical education and sports learning in extraordinary schools that teach children with special needs will learn to walk effectively if all elements synergize. The elements included are teachers, principals, and facilities supporting the teaching and learning process. Teachers become a major part of the implementation of learning. Therefore, the competence of teachers must be maintained to remain motivated to innovate in making their learning preparation, including the preparation of students in the circle of extraordinary schools.

To help children with special needs in improving physical fitness through the introduction and planting of positive attitudes and mobility skills of various 
physical activities and teachers who play a role in the development of motivation in children, among others, the development of aspects: (1) organic, (2) neuromuscular, (3) perceptual, (4) social and (5) emotional. Fitnessjasmani is a very important aspect of the overall fitness of the body that gives a person the ability to live a productive life and can adjust to any physical load that is worth it. Furthermore, improving the physical fitness of children with special needs is not easy but special tips are needed, such as presenting fun learning, especially in physical education learning. To stimulate students' motor skills and learning motivation.

Preparing for careful learning is as complete as the characteristics of children with special needs in the teaching and learning process to gain learning experience by providing some introductions that refer to the anticipation component[5]-[10]. In opening the lesson the teacher prepares the learners by developing their interest in the lesson. In preparing learners the teacher conveys what will be learned and its relationship with the previous lesson and current activities or that will come.

Physical fitness is one of the indicators in determining the dynamic healthy degree of a person who becomes the basic physical ability to be able to carry out the task that must be carried out. With a healthy and fit physique, one can carry out daily activities optimally. While motoric ability is one of the important fitness indicators in each individual that is closely related to the achievement of quality $\mathrm{T}$-motion skills can tribs kinds of basic motion that need to be developed optimally in childhood, namely: (1) locomotor movements; (2) non-locomotor movements; and (3) manipulative motion. Various physical activities carried out to improve physical fitness and children's health cannot be separated from the development of basic motion.

Physical education, especially in children with special needs, should prioritize the function of organ formation, thus physical education in elementary schools is obliged to develop the function of movement of children's organs as a whole. Multilateral development of children through learning and playing various sports skills needs to be a top priority although the available time is very limited.

Related to motor skills and physical fitness of children with disabilities who have the skills to perform a variety of basic movements, but still require the role of teachers to control the body to space and time.

The role of teachers in learning is someone responsible for the education of their students individually and classically, in the school environment and outside the school. In law 14 of 2005 concerning Teachers and Lecturers Chapter, I Article 1 teacher are professional educators with the main task of educating, teaching, guiding, directing, training, assessing, and evaluating learners on early childhood education pathways of formal education, elementary education, and secondary education. A teacher is a person who has the experience and knowledge in his field, so he should educate and give the knowledge he has to the learner so that the learner becomes smarter [8]-[17]

In Indonesia, many studies conducted about children with special needs, namely in the results of their research can be concluded that hyperactive behavior of children with special needs is one of the behaviors that are quite difficult to handle, especially by teachers in schools. This behavior of children with special needs is indicated by the behavior of frequent movement, unwillingness to shut up, over-talk, and running around often disturbing people around and sometimes silence and solitude [18]-[23]. While internationally in this study it can be concluded that hyperactive behavior is the behavior of a person who shows excessive activity, does not want to be silent, his attention is easily distracted, and concentration is less [24]-[30]. Thus the need to do physical activity is one of them through motor skills. physical activity is an activity that is done to maintain physical quality[35]

Based on the phenomenon in the form of facts, researchers provide solutions in the form of alternatives, one of which is through scientific studies on the analysis of motoric abilities of children with special needs reviewed from the role of teachers and physical fitness comparisons.

\section{METHODS}

The survey method used in this study is comparatively designed. The research was conducted in January-March 2021 at SLB Negeri Sukoharjo and SLB Negeri Karanganyar, Central Java Province, Indonesia. Target this research is all SLB students in Central Java while the research subjects are students of SLBN Sukoharjo and SLBN Karanganyar province of Central Java numbered 60 people, with the provision of 30 children with special needs with characteristics aged 13-15 years with the gender of the son consists of 15 people SLBN Karanganyar and 15 people SLBN Sukoharjo and teachers as many as 30 people consisting of 15 people SLBN Karanganyar and 15 people SLBN Sukoharjo The data collection techniques in this study used physical fitness tests and questionnaires. Explanation of data collection techniques can be described as follows: (1) Indonesian physical fitness test consists of 50-meter running test, pull-ups, sit-ups, vertical jump, and modified 1000 meter run; (2) the teacher role questionnaire is conducted employing two techniques, namely (a) shared online,(b) shared directly. Online questionnaires can be accessed through the link: https://docs.google.com/forms/d/1Q1 XMKSRdg6b8 qZDXXgTwWo3wI-JrAwu5LnaLSh4FAc/edit while directly shared customer research with a statement strongly agree, agree, doubt, disagree and strongly disagree; which consists of indicator teachers as educators, escorts, designers of learning, artists/actors, 
mediators, and motivators. The physical fitness norms can be seen in the following table:

TABLE I. TKJI VALUE AgE 13-15 YEARS

\begin{tabular}{|c|c|c|c|c|c|}
\hline \multirow{2}{*}{ Test items } & \multicolumn{5}{|c|}{ value } \\
\cline { 2 - 6 } & 5 & 4 & 3 & 2 & 1 \\
\hline 50_meter Run & $\leq 6.7 "$ & $7.3 "-8.3 ”$ & $\begin{array}{c}6.8 ”- \\
7.6 "\end{array}$ & $\begin{array}{c}7.7 ”- \\
8.7 ”\end{array}$ & $\geq 10.4$ \\
\hline Pull ups & $\geq 16$ & $11-15$ & $6-10$ & $2-5$ & $\leq 1$ \\
\hline Sit Ups & $\geq 38$ & $28-37$ & $19-27$ & $8-18$ & $\leq 7$ \\
\hline Vertical jump & $\geq 66$ & $53-65$ & $42-52$ & $31-41$ & $\leq 30$ \\
\hline Run 1000 & $\leq 3.04 "$ & $3.05 "-$ & $3.54 ”-$ & $4.47 "-$ & $\geq 6.05 "$ \\
meters & & $3.53 ”$ & $4.46 ”$ & $6.04 ”$ & \\
\hline
\end{tabular}

Source: formulated from TKJI test

TABLE II. ClAASSIFICATION OF TKJI AGE 13-15 YEARS RESULTS

\begin{tabular}{|c|c|l|}
\hline No. & Value Total & \multicolumn{1}{|c|}{ Classification } \\
\hline 1 & $22-25$ & Very Good \\
\hline 2 & $18-21$ & good \\
\hline 3 & $14-17$ & keep \\
\hline 4 & $10-13$ & less \\
\hline 5 & $5-9$ & Less Once \\
\hline
\end{tabular}

Source: formulated from TKJI test

The data analysis used in this study is t_test at a significant level $\alpha=0.05$ to determine the difference in the role of teachers and physical fitness of children with special needs. An overall analysis of this data uses SPSS version 23applications.

\section{RESULTS}

Based on the results of the descriptive analysis found several things, namely identification about: (i) physical fitness; and (ii) the role of teachers consisting of educator teachers, mentors, designers of learning, artists/actors, mediators, and motivators, can be explained as follows.

TABLE III. DESCRIPTIVE ANALYSIS RESULtS

\begin{tabular}{|l|c|c|c|c|}
\hline \multirow{4}{*}{ Statistics } & \multicolumn{4}{|c|}{ Variable Research } \\
\cline { 2 - 5 } & \multicolumn{3}{|c|}{ Physical Fitness } & \multicolumn{2}{c|}{ Role of Teacher } \\
\cline { 2 - 5 } & $\begin{array}{c}\text { SLBN } \\
\text { Karanganyar }\end{array}$ & $\begin{array}{c}\text { SLBN } \\
\text { Sukoharjo }\end{array}$ & $\begin{array}{c}\text { SLBN } \\
\text { Karangany } \\
\text { ar }\end{array}$ & $\begin{array}{c}\text { SLBN } \\
\text { Sukoharjo }\end{array}$ \\
\hline Samples & 15 & 15 & 15 & 15 \\
\hline Mean & 11.33 & 11.13 & 69.33 & 69.13 \\
\hline Range & 5 & 7 & 15 & 18 \\
\hline Minimum & 9 & 8 & 60 & 57 \\
\hline Maximum & 14 & 15 & 75 & 75 \\
\hline Std Deviation & 1.95 & 2.45 & 3.87 & 5.53 \\
\hline
\end{tabular}

Based on the results of the descriptive analysis in table 3 , it can be concluded that there are differences in physical fitness and the role of teachers of SLBN Karanganyar and Sukoharjo children with special needs. This is evidenced by the difference in average physical fitness value and teacher role of 11.33 and 11.13 different from the average difference of 0.10 . Thus it can be concluded that there are different roles of teachers and physical fitness in dealing with children with special needs. To strengthen the results of the descriptive analysis can be seen in the following histogram.

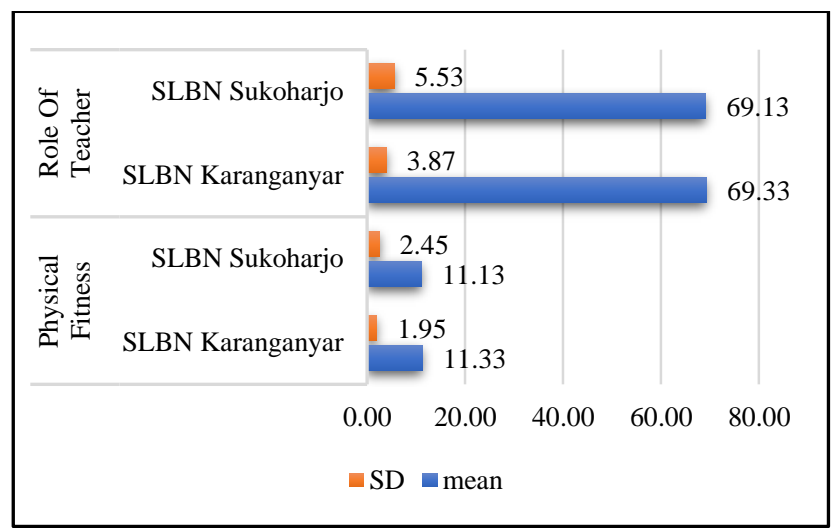

fig. I Results in Descriptive analysis of physical fitness and the role of teachers

Figure 1 illustrates that physical fitness and the role of teachers in outstanding schools are mutually supportive entities in improving the motoric abilities of children with special needs reviewed from physical fitness and the role of teachers. Interestingly here that the role of teachers consisting of teachers educators, mentors, designers of learning, artists/actors, mediators, and motivators in accompanying children with special needs. Furthermore, after knowing the difference in average then conducted a test of normality of data, Normality test requirement is normally distributed data if $\mathrm{KS}-\mathrm{Z} \geq \alpha=0.05$ otherwise the data is assumed not to be normally distributed if $\mathrm{KS}-\mathrm{Z} \leq \alpha=0.05$. For more details can be described as follows;

TABLE IV. DATA NORMALITY TEST RESULTS

\begin{tabular}{|l|c|c|c|c|}
\hline \multirow{4}{*}{ Statistics } & \multicolumn{4}{|c|}{ Variable Research } \\
\cline { 2 - 5 } & \multicolumn{2}{|c|}{ Physical Fitness } & \multicolumn{1}{c|}{ Role of Teacher } \\
\cline { 2 - 5 } & $\begin{array}{c}\text { SLBN } \\
\text { Karanganyar }\end{array}$ & $\begin{array}{c}\text { SLBN } \\
\text { Sukoharjo }\end{array}$ & $\begin{array}{c}\text { SLBN } \\
\text { Karangany } \\
\text { ar }\end{array}$ & $\begin{array}{c}\text { SLBN } \\
\text { Sukoharjo }\end{array}$ \\
\hline $\begin{array}{l}\text { Kolmogorov- } \\
\text { Smirnov Z }\end{array}$ & 0.908 & 0.820 & 0.541 & 0.899 \\
\hline $\begin{array}{l}\text { Asymp. Sig. } \\
\text { (2-tailed) }\end{array}$ & 0.382 & 0.511 & 0.931 & 0.394 \\
\hline
\end{tabular}

Based on the results of the normality test table 4 on physical fitness data and the role of teachers in normally distributed outstanding schools or KS-Z $>\alpha=0.05$. Thus it can be concluded that the sample of this study as a whole is normally distributed. Once the conditions are met, the t_test test to make a difference between physical fitness and the role of teachers in outstanding schools can be seen in the following table. 
TABLE V. PAIRED SAMPLES TEST (T_TEST)

\begin{tabular}{|c|c|c|}
\hline \multirow{3}{*}{ Statistics } & \multicolumn{2}{|c|}{ Paired Samples Test } \\
\hline & Physical Fitness & Role of Teacher \\
\hline & $\begin{array}{l}\text { SLBN Karanganyar_ } \\
\text { SLBN Sukoharjo }\end{array}$ & $\begin{array}{c}\text { SLBN } \\
\text { Karanganyar_- } \\
\text { SLBN Sukoharjo }\end{array}$ \\
\hline t_count & 0.212 & 0.140 \\
\hline Sig. (2-tailed) & 0.382 & 0.890 \\
\hline
\end{tabular}

Based on analysis paired samples to test (t_test) physical fitness and the role of teachers in outstanding schools in table 5 above obtained $t_{\text {_count }}$ values of

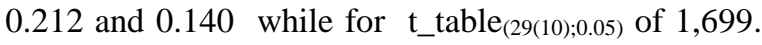
Thus it can be concluded that the correlation coefficient (paired samples test or t_test) between physical fitness and the role of the teacher is insignificant or $\mathrm{H}_{0}$ internal and rejected $\mathrm{H}_{1}$. This means that there is no difference in physical fitness and the role of teachers in dealing with children with special needs.

The overall physical fitness and role of teachers in dealing with children with special needs of SLBN Karanganyar and Sukoharjo can be generalized or can apply to the population as a whole of children with special needs where the sample of 30 people in this study.

\section{DISCUSSION}

Based on the results of the data analysis can be stated that the motor skills of children with special needs are reviewed from the role of teachers and physical fitness differences there are no significant differences. This is evidenced by the results of analysis paired samples test (t_test) physical fitness and the role of teachers in outstanding schools obtained $t_{-}$count scores of 0.212 and 0.140 while for $\mathrm{t} \_$table $_{(29(10) ; 0.05)}$ of 1,699 . Thus it can be concluded that the paired samples test (t_test) between physical fitness and teacher role is insignificant or $\mathrm{H}_{0}$ is accepted and rejected $\mathrm{H}_{1}$.

The research on motor skills of children with special needs is reviewed from the role of teachers and physical fitness differences there are no significant differences, but in this study, researchers tried to conduct a survey research approach by utilizing the motor skills of children with special needs reviewed from the role of teachers and differences in physical fitness. The research conducted by Galang Sulaksono in this research aims to find out empirically how big the level of motor skills of elementary school students is. Researchers want to describe the ongoing situation, without hypothesis testing, focusing on the motor skills of grade IV and V students of SD Negeri Pojok I Kec. Kwadungan Kab. Ngawi [32]. Understanding the dynamics of the lives of children with special needs; development and how the environment can become a supportive social agent; These children need the stimulus of the flower, special care from the family and school agencies, and what is very important is the need for affection and attention from parents and adults around it. The learning process or teaching and learning activities cannot be separated from the existence of teachers. Without teachers learning will be difficult to do, especially in the framework of the implementation of formal education, teachers become a very vital party. Teachers have the most active role in the implementation of education to achieve the educational goals to be achieved.

The results of the study were reviewed in a literature study with the results of previous research, aimed at making discussing the results of the research with references to be used as guidelines for coaches, sports scientists, and other stakeholders. In the context of the library review, no research has been found on determining the motoric abilities of children with special needs reviewed from the role of teachers and physical fitness comparisons

This research was conducted in the form of a survey on the physiology of humans, especially in children with special needs as the object of research which of course has many weaknesses and limitations, although it has been attempted to do the maximum and objective control as possible. Weaknesses and limitations need to be put forward as a consideration in interpreting and generalizing the findings of this study. limitations of research that need to be put forward.

This study only involves research samples that are children with special needs and the role of teachers in the school environment is extraordinary, so this research can only be generalized to groups of children with special needs. It is recommended that the women's sample is also used as a sample because the analysis of the motoric ability of children with special needs is reviewed from the role of the teacher and physical fitness comparison covers the whole aspect of the test to generalize to the characteristics of children with special needs.

\section{CONCLUSIONS}

Based on these findings, that to improve physical fitness, the need to exercise physical activity, one of which is through motoric ability training through the role of teachers consisting of teachers as educators, mentors, designers of learning, artists/actors, mediators, and motivators in children with special needs in the learning process of teaching physical education in schools. The results of this study also contribute to expanding the current knowledge of motoric abilities of children with special needs reviewed from the role of teachers and physical fitness comparisons. Given that this study only involves small samples, caution needs to be taken to determine the motoric ability of physical fitness and more effective and efficient learning in Children with Special Needs. 


\section{ACKNOWLEDGMENT}

Thank you to Universitas Muhammadiyah Surakarta for granting research permits and fully funding this research through the tri dharma Integration Grant in the fiscal year 2021. For SLBN Sukoharjo and Karanganyar who delegate and permit and facilitate research and research team Hibah Integrasi Tridharma contribute and spend time edifying in this research

\section{REFERENCES}

[1] H. Ringeisen, C. Casanueva, M. Urato, and T. Cross, "Special health care needs among children in the child welfare system," Pediatrics, 2008, doi: 10.1542/peds.2007-3778.

[2] L. Furman, "What is attention-deficit hyperactivity disorder (ADHD)?," J. Child Neurol., vol. 20, no. 12, pp. 994-1002, 2005, doi: 10.1177/08830738050200121301.

[3] R. K. Rahimabadi, "The nature of Meta cognition," no. May, 2014.

[4] C. H. P. Sit, K. J. Lindner, and C. Sherrill, "Sport participation of Hong Kong Chinese children with disabilities in special schools," Adapt. Phys. Act. Q., 2002, doi: 10.1123/apaq.19.4.453

[5] R. Sijabat, "Gaya Hidup Yang Memengaruhi Kesehatan Anak Berkebutuhan Khusus di SLB Negeri Salatiga," J. Keperawatan Muhammadiyah, 2018, doi: 10.30651/jkm.v2i2.1069.

[6] M. (PLB F. U. N. P. Iswari, "Pendidikan Kecakapan Hidup Bagi Anak Berkebutuhan Khusus," Repository.Unp.Ac.Id, 2007.

[7] Sambira and L. I. Badiah, "Karakteristik dan Kebutuhan Anak Berkebutuhan Khusus," Karakteristik dan Kebutuhan Anak Berkebutuhan Khusus, 2018.

[8] E. R. Yuliawan, "Implementasi Kebijakan Pengelolaan Asesmen Anak Berkebutuhan Khusus Sekolah Inklusi Di Dinas Pendidikan Pemuda Dan Olahraga Provinsi Diy," J. Kebijak. Pendidik., 2017.

[9] J. Thompson, Memahami Anak Berkebutuhan Khusus. 2017.

[10] K. Y. Pratama, "Implementasi Kebijakan Pembinaan Olahraga Anak Policy Implementation of Student With Special Need Sport," J. Kebijak. Pendidik., 2019.

[11] Republik Indonesia, "Undang-Undang Nomor 14 Tahun 2005 tentang Guru dan Dosen," Sekr. Negara, 2005.

[12] H. Heriyansyah, "Guru Adalah Manajer Sesungguhnya Di Sekolah,” Islam. Manag. J. Manaj. Pendidik. Islam, 2018, doi: 10.30868/im.v1i01.218.

[13] N. Sepriyanti, "Guru Profesional Adalah Kunci Mewujudkan Pendidikan Berkualitas," Al-Ta lim J., 2012, doi: 10.15548/jt.v19i1.8.

[14] S. Suprihatin, "Upaya Guru Dalam Meningkatkan Motivasi Belajar Siswa," Promosi (Jurnal Pendidik. Ekon., 2015, doi: 10.24127/ja.v3i1.144.

[15] Norashid Bin Othman and Hamzah Bin Md.Omar, "Beban Tugas dan Motivasi Pengajaran Guru di Sekolah Menengah Daerah Ranau," J. Pemikir Pendidik. (Journal Educ. Thinkers), 2014.

[16] E. H. Mulyana, "Guru Berkualitas: Profesional dan Cerdas Emosi,” J. Saung Guru, 2010.

[17] A. H. Saragih, "Kompetensi Minimal Seorang Guru Dalam Mengajar,” J. Tabularasa, 2008.

[18] A. Kirom, "Peran Guru Dan Peserta Didik Dalam Proses Pembelajaran Berbasis Multikultural," Al Murabbi, 2017.

[19] Republic of Indonesia, "Undang-Undang Republik Indonesia, Tentang Guru dan Dosen," Pemerintah Indones., 2005.

[20] S. Wahyuni, "Profesi Guru Adalah Panggilan Ilahi," Antusias, J. Teol. dan Pelayanan, 2014.

[21] Kunandar, Penilaian Autentik (Penilaian Hasil Belajar Pesrta Didik Berdasarkan Kurikulum 2013. 2015.

[22] F. A. Rahmadi, G. Hardaningsih, and R. Pratiwi, "Prevalensi dan jenis masalah emosional dan perilaku pada anak usia 9-11 tahun dengan perawakan pendek di Kabupaten Brebes," J. Gizi Indones. (The Indones. J. Nutr., 2016, doi: 10.14710/jgi.3.2.116-119.

[23] T. S. Situmorang, N. Nurnaningsih, and R. Sutomo, "Perbedaan Perilaku Anak Prasekolah Berdasarkan Pola Pengasuhan," Sari Pediatr., 2017, doi: 10.14238/sp18.4.2016.314-9.

[24] E. Kholilah and Y. Solichatun, "Terapi Bermain Dengan CBPT (Cognitive Behavior Play Therapy) Dalam Meningkatkan Konsentrasi Pada Anak ADHD," Psikoislamika J. Psikol. dan Psikol. Islam, 2018, doi: 10.18860/psi.v15i1.6662

[25] A. Andayani and N. Christiani, "Pengaruh Hipnoterapi dan Healing Touch Terhadap Perilaku Hiperaktif pada Anak Autis di SLB N Ungaran," Indones. J. Midwifery, 2019, doi: 10.35473/ijm.v2i2.284.

[26] A. D. Anggraeni, "Studi Fenomenologi: Pola Asuh Orangtua Pada Pembelajaran Motorik Halus Anak Attention Deficit Hyperactivity Disorder (ADHD) Usia Pra Sekolah," J. Ilmu Kesehat. Bhakti Husada Heal. Sci. J., 2019, doi: 10.34305/jikbh.v10i2.89.

[27] L. T. Mirtha and R. Sekartini, "Pengaruh Kepatuhan Latihan Senam Kesegaran Jasmani 1988 Terhadap Perilaku Anak dengan Gangguan Pemusatan Perhatian/Hiperaktivitas," Sari Pediatr., 2016, 
doi: 10.14238/sp18.2.2016.146-56.

[28] K. K. S. Voeller, "Attention-deficit hyperactivity disorder (ADHD)," Journal of Child Neurology. 2004, doi: 10.1177/08830738040190100901.

[29] S. J. J. Kooij et al., "European consensus statement on diagnosis and treatment of adult ADHD: The European Network Adult ADHD," BMC Psychiatry, 2010, doi: 10.1186/1471244X-10-67.

[30] D. Demontis et al., "Discovery of the first genome-wide significant risk loci for attention deficit/hyperactivity disorder," Nat. Genet., 2019, doi: 10.1038/s41588-018-0269-7.

[31] S. N. Visser et al., "Trends in the parent-report of health care provider-diagnosed and medicated attention-deficit/hyperactivity disorder: United States, 2003-2011," J. Am. Acad. Child Adolesc. Psychiatry, 2014, doi: 10.1016/j.jaac.2013.09.001.

[32] S. V. Faraone et al., "Attentiondeficit/hyperactivity disorder," Nat. Rev. Dis. Prim., 2015, doi: 10.1038/nrdp.2015.20.

[33] G. Polanczyk, M. S. De Lima, B. L. Horta, J. Biederman, and L. A. Rohde, "The worldwide prevalence of ADHD: A systematic review and metaregression analysis," Am. J. Psychiatry,
2007, doi: 10.1176/ajp.2007.164.6.942.

[34] P. Shaw, A. Stringaris, J. Nigg, and E. Leibenluft, "Emotion dysregulation in attention deficit hyperactivity disorder," American Journal of Psychiatry. 2014, doi: 10.1176/appi.ajp.2013.13070966.

[35] G. Jariono and N. Subekti, "Sports Motivation Survey And Physical Activity Students Of Sport Education Teacher Training And Education Faculty FKIP Muhammadiyah University Surakarta," Kinestetik J. Ilm. Pendidik. Jasm., 2020, doi: 10.33369/jk.v4i2.12449.

[36] G. Sulaksono, U. Doktor, and N. Magetan, "Unwahas Sport And Educations Analisis Kemampuan Motorik Siswa Kelas IV dan V SD Negeri Pojok I Kecamatan Kwadungan Kabupaten Ngawi Tahun 2019 / 2020," vol. 2, no. 1 , pp. 1-8, 2021.

[37] D. Ratrie Desningrum, "Psikologi Anak Berkebutuhan Khusus," Depdiknas, pp. 1-149, 2007.

[38] S. Arifin, "Peran Guru Pendidikan Jasmani Dalam Pembentukan Pendidikan Karakter Peserta Didik," Multilater. J. Pendidik. Jasm. dan Olahraga, vol. 16, no. 1, 2017, doi: 10.20527/multilateral.v16i1.3666. 